\title{
Refugee Repatriation During Conflict: A New Conventional Wisdom
}

\author{
Julie C. Barbero
}

There are over 16.5 million refugees and people in refugee-like situations around the world, most of them in Africa. In fact, according to the World Refugee Survey, there are a total of 5,340,800 people in Africa who can be classified as refugees, asylum seekers and people in refugee-like situations who require international protection and/orassistance. Consequently, close to one in every three such persons is of African origin (Hamilton 1992, 33).

Further, in recent months worldwide, some 10,000 refugees per day have been forced to flee their homelands, while some 5,000 per day are returning home under the auspices of the United Nations High Commissioner for Refugees(UNHCR 1992,2). In addition, many more repatriate "spontaneously" every day. Although the situation is critical, durable solutions have not been forthcoming until now.

\section{The "Old" Conventional Wisdom}

Over the past four decades, the most often cited durable solutions to the plight of refugees have been either voluntary repatriation or settlement in a country of asylum or third country. Voluntary repatriation is the one often deemed as the most durable. This wisdom, reflective of the immediate post-World War II era, is bolstered by a system of tripartite agreements reached between the country of origin, the host country and UNHCR, and is usually based on an amelioration of the circumstances that forced the originalexodus. This belief has both governed the way institutions regard and respond to refugee issues. Yet while the voluntary concept of repatriation has not changed, the changing nature of conflicts and refugee flows has created, in many instances,

Julie Barbero is a researcher at the International Organization for Migration. a deadlock in the implementation of this "old" conventional wisdom.

The deadlock is, to a great extent, a result of insurgency movements and counterinsurgency strategies that have become the norm. This has made it increasingly difficult for multilateral relief agencies to determine with whom negotiations should be conducted or to distinguish the once clear-cut boundaries between peace and war, combatant and noncombatant. Today the trigger words are "instability" and "relative stability" - all too often, civilians become the casualties of conflict. Consequently, the definition of "combatant" has also been blurred and civilians have become the targets of insurgents from the Horn to West Africa; from the Maghreb region to southern Africa.

It has been stated that "the scale and scope of Africa's recent wars has put them beyond the control of governments or global institutions, requiring a reassessment of international humanitarian law and the strategies used to assist the victims of conflict" (Cater 1991,26). Thus, orderly refugee repatriations following independence are becoming increasingly rare. More often refugees languish in camps in growing numbers-close to 204,000 Rwandan nationals who have sought refuge abroad since 1961 and over one million Ethiopian nationals whose exodus also began in 1961 are cases in point (Stein 1992, 4).

Indeed, the number of refugees or people in refugee-like situations has increased in recent years due to the increase in instability, human rights abuses and socio-economic hardships brought on by conflict, drought, famine and political/economic mismanagement. This number has also been on the rise due to the dearth of durable solutions-that is, refugees remain refugees longer than in the past with little or no hope for an acceptable outcome to their plight.

\section{The "New" Conventional Wisdom}

The "old" conventional wisdom was developed and applied to refugee situations that were often different from current situations. Today in Africa, where conflicts are prolonged and peace seems a remote possibility, the international community and donors have been forced to ask which comes first: peace or repatriation and development activities.

Under the old conventional wisdom, peace was often given priority with donors opting to fund projects with more tangible and immediate results-that is, repatriation that signalled the resolution of conflicts or the end of a struggle for independence, as in Namibia and Zimbabwe, for example. (Yet, in the case of the Namibian repatriation, the country was not prepared to receive such large numbers of returnees, despite internationally organized repatriation. Thus today, some two and a half years after the return of over 43,000 Namibians following independence, unemployment ranges between 30 and 40 percent and is further aggravated by a large number of Namibians who need training and skills upgrading (International Organization for Migration 1992, 14).

Repatriation is often enforced through the reality that only about 1 percent of the world's refugee population is settled in third countries. For the remaining refugees, the host countries are not always prepared or are unable to grant refugees integration, permanent status or citizenship. In the words of the former UN High Commissioner for Refugees, Poul Hartling, "the massive arrivals of refugees [are to] low-income countries where often no durable solutions are at hand" (Stein 1992, 4). Consequently, refugees often return home to situations of war, instability and conflict.

Indeed during 1992, many South African exiles returned to their homeland

Refuge, Vol. 12, No. 8 (March 1993) 
despite persistent conflict. In the May 1992 issue of Refugees, "South Africa: Facing Reality," it was stated that against this backdrop, many South Africans have asked why the exiles want to return. Yohannes Gebresellassie states that "In the African context especially, the sense of attachment which refugees have towards ... their homeland is strong. Recent history has repeatedly demonstrated that when conditions have changed for the better, African refugees waste no time in setting out on the road back home" (Gebresellassie 1992, 3).

It is becoming increasingly clear that complete peace is not always a prerequisite to repatriation or reintegration/development programs. During the May Ethiopian Rehabilitation Campaign Donors' Conference, His Excellence Meles Zenawi stated, "Some would say that peace and stability are prerequisites for the rehabilitation of Ethiopia. We believe that peace, democracy and economic recovery must go hand and hand, and reinforce one another" (Zenawi 1992, 2). Therefore, in promoting complete peace, the international community may be closing off other viable options.

Refugees, on the other hand, are less likely to adopt this wait-and-see attitude and often refurn to their homelands despite the lack of international assistance. Governments, international organizations and NGOs should explore other available options-develop modalities and implement concrete policies to ensure that repatriations occur under the safest possible conditions, and that reintegrations are successful. The case of Somalia demonstrates that solutions can sometimes only be promoted through international interventions in times of conflict and also highlights the dangers of adopting a wait-and-see stance.

\section{The Relief to Development Continuum}

A new approach, a relief to recovery to development continuum is more in line with today's realities. In fact, the International Organization for Migration (IOM) has played an integral role in this continuum over the last decade. In recent years, there have been IOM repatriation and return programs to areas of "insta- bility" or "fragile peace"; these programs have concurrently promoted respective peace processes while assisting in the development of the countries of return.

IOM programs can be divided into two categories of return-migration for development and national migration and refugee resettlement activities. Each category has examples of returns that occur under less than ideal security situ-

can nationals have returned under the auspices of the IOM program.

\section{IOM's Place in the Continuum: Program for the Reintegration of Qualified Nationals}

At the United Nations ECOSOC meeting held in July 1992, the UNHCR liaison officer stated, "It is a matter of great concern ... that returnees will be going back

\section{The case of Somalia demonstrates that solutions can sometimes only be promoted through international interventions in times of conflict and also highlights the dangers of adopting a wait-and-see stance.}

ations. By all current indications, such returns will continue to increase in the future. This paper will explore IOM programs-their successes, shortfalls and usefulness during conflict and the ways in which IOM has attempted to fill development gaps in countries in which there is continuing conflict or fragile peace. It was recently stated at the UN Economic and Social Council Plenary that:

Humanitarian diplomacy can often provide a catalyst toward the successful settlement of issues directly related to the human emergencies... [and may] ... provide tangible starting points for furthering political negotiations ... there will be no political settlement in Yugoslavia if Sarajevo is starved into submission ... there will be no security in Somalia without an adequate food supply (Marks 1992, 3).

Likewise, there will be inadequate medical care in Angola without the return of Angolan doctors to a country devastated by sixteen years of conflict and the University of Asmara will be insufficiently staffed without the return of Eritrean professors to their newly emerging nation. One important role of the IOM Program for the Return of Qualified African Nationals, as well as other similar programs, is to intervene and help to forestall such problems.

Highly qualified and skilled African nationals leave the continent for many reasons, mostly because of war and instability, and often voluntarily return to less than ideal conditions to begin the reconstruction process. Many such Afri- to countries devastated by war and to areas inhabited by displaced persons. The capacity of such areas to absorblarge numbers of returnees needs to be enhanced by comprehensive programmes for political, economic and social reconstruction" (Peters 1992, 7). In other words, repatriation must entail more than the return to one's homeland. IOM's program for the reintegration of qualified African nationals is an integral component of a comprehensive return and reintegration approach.

The IOM's migration for development policies, whether carried out in countries at peace or in situations of fragile peace, follow the basic philosophy that return should include an integration into countries' development plans. Yohannes Gebresellassie states, "African refugees are not only peasants and uneducated farmers with a rural background. There are also many highly skilled and educated African refugees, whose numbers are increasing" (Gebresellassie 1992, 1). It is believed that such refugee-cum-returnees can and should play a vital role in their country's development process.

IOM has, In fact, implemented the European Community-funded reintegration program successfully in situations of both peace and fragile peace. During the past decade, IOM has returned over 5,500 qualified African professionals and their family members to Africa in order to fill positions vital for development and nation-building in 
Angola, Mozambique and Ethiopia. This return process is initiated and carried out with the voluntary consent of the prospective returnees with the goal of creating hope for future development and normalization.

Such IOM experiences have shown that return for development activities can come first. For example, Mozambique has participated in the IOM program since the late 1980s. Since that time, IOM-assisted professionals have returned to Mozambique to help fill gaps in the country's stunted development process caused by almost two decades of civil war. They will further assist in facilitating the reintegration of the over 200,000 Mozambicans who have returned (and continue to return) during the conflict. It has been noted that such peacemaking initiatives "could be a critical factor in limiting or controlling violence and could make a positive contribution to the overall resolution of conflicts" (Butler 1992).

Angola also started reconstruction activities, despite a still precarious security situation, and began participating in the IOM return program before a complete peace had been reached. Despite the problems still facing Angola, one IOM returnee, a civil engineer, returned to his homeland in 1991. This Angolan national, who was forced into exile in 1975 during the colonial war, stated upon his return, "It was always my wish to go back and now I shall work on the reconstruction of my country, on the bridges and dams I helped to construct years ago."

Thus the "spontaneous" returnees who arrive daily in Mozambique and Angola will be able to benefit immediately from the IOM-assisted professionals-doctors, health care personnel, teachers and engineers. It is hoped that such returnees will be able to form a "zone of safety" for return and development activities. Closer cooperation between IOM and such countries as Mozambique and Angola will help to further return for development activities. This, in turn, may foster the pull factors that encourage nationals residing abroad to return for nation rebuilding activities, even in situations where a complete peace has not been reached.

\section{The Return and Reintegration of Rejected Asylum Seekers}

In western Europe today, there are close to 318,000 asylum seekers with Ghanaians and Zaireans comprising the largest African groups-some 30,000 and 27,000, respectively (Moussalli 1990, 69). The number of unaccepted refugees and asylum seekers also continues to swell, as well as the factors that make asylum more difficult to attain. Indeed, the European Community has steadily sought a uniform policy on this matter. In addition, the practice of having safe country listings has increased the risks of asylum seekers being involuntarily returned to their country of origin. It has been stated services to ensure the safe and productive return of program participants.

Consequently, the program's operation is largely contingent upon the prevailing security situation in the country of reintegration. Returnees are prescreened and the economic and social situations in the countries of return are closely monitored. Particular attention is paid to detecting any developments that may affect the personal security of the returnees and their families. IOM structures in the receiving countries as well as its close working relations with UN agencies and the International Committee of the Red Cross (ICRC) assists in this respect.

These precautions help to ensure the safety of the returnees while productively integrating them into their home

\section{In addition, the practice of having safe country listings has increased the risks of asylum seekers being involuntarily returned to their country of origin.}

that this allows for " avoiding the necessity for case-by-case review and clearing the way for protection" (Goodwin-Gill, 1992, 38). In light of this, Winter states that "Harmonization, all too often, has meant that nations once more generous than their neighbors, now are introducing restrictive measures" (Winter 1991, $5)$. These actions have created a sociopolitical and moral quandary for both the traditional receiving countries and, most especially, for the asylum seekers.

Thus, as governments attempt to create uniformity in their approach, IOM has chosen to follow a multilateral approach, as in its participation in the Niagara-on-the-Lake conference concerning the fate of asylum seekers. Since the late 1970 s, IOM has been implementing a program for the reintegration or emigration of asylum seekers from various European countries. To date, IOM has assisted some 100,000 asylum seekers (close to half of this number have been reintegrated into their country of origin). This program has been carried out in close cooperation with voluntary agencies in both hosting and receiving countries and with government social countries. Indeed, often this return and reintegration option is far better than having asylum seekers languish in countries of asylum, often awaiting negative responses to asylum requests, or living in constant fear of deportation.

In the African context IOM, in cooperation with European governments, is developing programs for unsuccessful Ghanaian and Ethiopian asylum seekers. These programs will provide the rationale and structure to assist in the voluntary return and reintegration of such nationals into their home communities, following vocational training in either their current host countries or their countries of return. These programs also provide training for returnees with entrepreneurial skills and assist them in establishing small-scale enterprises. In Ethiopia, an IOM structure is being established and close contacts with the transitional government of Ethiopia have been developed. This close cooperation will help to ensure the safety of returnees to a land that is experiencing acute skilled manpower shortages due to a decade of drought, famine and civil war. 


\section{Bilateral Voluntary Contribution: Program for the Return and Reintegration of African Nationals}

In addition to these multilateral programs, IOM also implements bilateral programs sponsored by donor governments. One example is the program for the return and reintegration of African nationals funded by the Italian voluntary contribution. This program provides vocational training to non-EC nationals currently residing in Italy and facilitates their return either as employees or, where feasible, as self-employed.

The program is based on the assumption that a considerable number of African nationals who are presently residing in Italy would reestablish themselves in their country/region of origin if given the possibility to productively do so. During their stay in host countries, many African nationals have acquired knowledge and skills that could constitute the basis for a successful reintegration if utilized to its fullest extent. The program is jointly implemented with Italian institutions and regional administrations to provide further training and skills upgrading. This approach thereby assists developing countries in the nationbuilding process and may help to ameliorate the push factors that encourage the immigration of the most talented from developing countries. It is also a more efficient use of development funds (as most developing nations are not in a financial position to hire foreign advisers and technicians) and implies a longer term pay-off-that is, the return of nationals is usually longer, if not permanent, and thereby ensures a longer term transfer of knowledge and skills).

\section{Return and Reintegration Program to Eritrea}

IOM is in the early stages of establishing a return and reintegration program to Eritrea along Ethiopia's northern border. The provisional government of Eritrea has encouraged development programs that are integrated into the country's development plans and that emphasize the rehabilitation of areas of protected return. Such development activities are a precondition to large-scale organized repatriation.

In preparation for such mass voluntary return and as a start to the nation-building process, IOM has identified priority sectors in Eritrea and is currently returning selected nationals to the University of Asmara and to governmental bodies. The returning Eritrean professionals will help to rebuild their country after a long and destructive civil war that has left little infrastructure and a very weak human resource base. In addition, there are also projects to promote the development of Eritrea's public transport infrastructure and communications sector in joint ventures with Ital- ductive reintegration. Indeed, this is often the case in situations where return and reintegration may be difficult. The main national counterpart during the SARP operation has been the National Coordinating Committee for Repatriation (NCCR). The NCCR has helped to arrange technical training, assisted returnees in the start-up of small-scale businesses and self-employment schemes, and offered counselling for returnees facing difficulties during the reintegration period.

Many South Africans have returned "home" after having spent most or all of their adult lives in exile and it was aptly stated by Rogge and Akol that "for many

\section{During their stay in host countries, many African nationals have acquired knowledge and skills that could constitute the basis for a successful reintegration if utilized to its fullest extent.}

ian agencies. An IOM office has been opened in Asmara to facilitate the implementation of development programs in the country.

\section{The South African Repatriation Program}

IOM programs often promote an integrated approach, as demonstrated in Eritrea. This has also been the case in South Africa, in which a mass repatriation program has been complemented by a migration for development program. The South African Repatriation Program(SARP), which IOMoperates as UNHCR's implementing partner, is foremost among the organization's voluntary repatriation programs in Africa. Followingnegotiations lastyear, the government of South Africa and UNHCR agreed on a voluntary repatriation program for South African exiles. Since September 1991 UNHCR and IOM have jointly implemented SARP, and to date some 3,700 exiles have been repatriated on IOM-chartered aircrafts. Several thousands more from some thirty countries are expected to return before the program's conclusion. Throughout the program, UNHCR and IOM have worked closely with counterparts in South Africa to assist in a safe and pro- long-term refugees ... repatriation does not necessarily mean 'going home'" (Rogge and Akol 1989, 193). Nevertheless, South Africans continue togo home, and as the program continued through the winter and spring of 1992 , it was increasingly evident that ongoing SARP operations were not addressing the needs of South African professionals whose return is necessary for the development of their homeland. IOM offered its reintegration and job placement services to bridge this gap. Thus SARP created a complementary program to protect the return and reintegration of qualified South African nationals.

\section{The Program for the Return and Reintegration of Qualified South African Nationals}

In the spring of 1992, grants were received from the government of Luxembourg to initiate a program for the return of skilled, qualified and highly qualified South Africans to priority development sectors. Analysis of selected South African sectors indicated that there would be continual shortages of professionals, especially in engineering, computer science, science, medicine and management. According to the National Manpower Commission's 1989 report, 
South Africa is expected to have a shortfall of at least 228,000 professionals and technical workers by the year 2000 (Unterhalter and Wolpe 1990, E33).

Yet, despite the lack of qualified professionals and the increasing areas of deficiencies, what is most evident in the South African occupational structure has been the slow advancement of black nationals. Further, the present South African school system cannot facilitate substantial black advancement. This is an indication that, for the time being, the pool of trained black South African professionals will need to be tapped from abroad. The central role of a technically and managerially competent black leadership in the process of political transformation has been repeatedly stressed.

IOM has attempted to meet this need through the well planned return of professionals who will meet both the country's immediate needs and also serve as conduits for future training and skills transfer. Returnees also serve as important role models for the youngblack community, which, until recently, has had few black professionals to emulate.

IOM's African Scientists in Exile in Africa program, funded by the Sasakawa Peace Foundation, aims at securing long-term productive employment for qualified people in refugee-like situations through international migration and job-placement in Africa. Uganda, in particular, has been a targeted recipient country due to its recent history and the current desire of many Ugandans to return to their homeland. In 1986 the present government implemented radical measures to rehabilitate the country's social and economic infrastructures. At that time, there was a serious lack of qualified manpower. Consequently, the government has encouraged the return of its qualified nationals from industrialized nations and from neighbouring developing countries. One such Ugandan returned to his homeland in 1992, under the auspices of this IOM program, after thirteen years in exile as a refugee in Kenya. This small-scale entrepreneur returned to start an aluminum foundry, while another Ugandan electronics engineer returned from Ghana where he received a degree in electrical engineering.
Both Ugandan returnees will help to contribute to the development process of a country from which they fled over a decade ago.

However, sometimes after an analysis of certain national situations, it is determined that return is not immediately possible. Such was the case with a Sudanese doctor in Kenya, who recently migrated to Zimbabwe under the auspices of the program. This Sudanese national, with specializations in ophthalmology, paediatrics and gynaecology, has taken a senior position in Zimbabwe's Ministry of Health.

\section{The IOM Pipeline: Somalia and Somaliland}

IOM continues to monitor closely the situation in Somalia and the newly emerging Somaliland. The Horn of Africa in general and this region in particular have suffered from the tragic effects of drought, famine and conflict, which have resulted in one of the largest displaced/refugee populations in the world. Current UN estimates place the number of people in need of emergency assistance in the Horn at some twentythree million, with some seven million displaced and 1.5 million refugees. (SEPHA 1991, 12).

Pending the outcome of an IOM mission to Somalia in September, it will be determined whether the situation in the country is conducive for recommencing IOM return and reintegration activities. In the meantime, over the last two years, five Somali doctors have returned to their homeland under the auspices of the IOM/EC return and reintegration program. IOM also continues to register qualified Somalis, especially health care professionals. Further, close contact is maintained with other concerned international organizations, especially UNHCR, the World Health Organization and the ICRC, in order to encourage an integrated approach to development. In addition, IOM is helping to bolster Kenya and otherneighbouring countries under both refugee and return for development programs to promote a recognition of the role of neighbouring nations in forming a "front of peace" and in establishing regional support networks.

\section{Conclusion}

It is becoming increasingly clear that complete peace is not always a prerequisite to either return or reintegration/development programs. As has been reflected in IOM's migration for development and refugee resettlement experience in Africa, the international community can target certain groups to serve as a first strike team during times of fragile peace. Such "first strike" returnees will facilitate the reintegration of other returning refugees and set in place the necessary accompanying infrastructure, thereby helping to start up much needed development activities. It has been noted that neighbouring countries can and should help to form a "front of peace." This regional approach should be encouraged through the bolstering of neighbouring countries' infrastructure and development. International organizations, NGOs and intergovernmental organizations, such as IOM, can serve as important conduits in this process through which peace, democracy and economic recovery are concurrently promoted and achieved. 圈

\section{References}

Butler, Richard. 21 July 1992. Statement of the Permanent Representative of Australia to the Economic and Social Council Plenary on Agenda Item 9, Special Economic, Humanitarian and Disaster Relief assistance, July 21.

Cater, Nick. 1991. "Victims of Violence." Refugees (May).

Gebresellasie, Yohannes. 1992. "Africa's New Refugees: An Overview." Refuge 11, no. 3 (March): 1-7.

Goodwin-Gill, Guy. 1992. "New Mandate? What New Mandate?" Refugees.

Hamilton, Virginia, and Bill Frelick, eds. 1991. World Refugee Survey 1991. Washington, D.C.: American Council for Nationalities Service.

International Organization for Migration. 1991. International Cooperation in the Field of Migration: A Symposium with LusoPhone Countries. Lisbon, Portugal, June.

1992. Second Evaluation Seminar on the Program for the Reintegration of Qualified African Nationals, Harare, Zimbabwe, February. 